\title{
INSIGHTS INTO THE WORKERS' PARTICIPATION IN MANAGEMENT IN AN INDIAN SUGAR INDUSTRY: A DIAGNOSTIC STUDY
}

\author{
Ms. N.Anupama ${ }^{1}$ \\ ${ }^{1}$ Research Scholar, \\ Dept. of Management, \\ Dravidian University, \\ Kuppam, Chittoor, \\ Andhra Pradesh.
}

\author{
Prof.G.L.Narayanappa ${ }^{2}$ \\ ${ }^{1}$ Dean, \\ School of Commerce and Management, \\ Dravidian University, \\ Kuppam, Chittoor, \\ Andhra Pradesh.
}

\section{INTRODUCTION}

'JUPITER' sugars India LTD was founded in the year 1941 in southern India as a private sugar factory. Later it has enhanced its production from $1000 \mathrm{TCD}$ to $8500 \mathrm{TCD}$ in the year 1962. It was amalgamating of many sub units and multi locational products into its main unit. The company has focussed its attention on various projects and substantial resources. Subsequently, they have decided to organise the company into two units one in southern India and one in northern India.

Sugar industry is one of the most important agro-based industries in India and is extremely accountable for creating major impact on rural economy in particular and country's economy in broad-spectrum. Sugar has been yield in the Indian subcontinent since ancient times and then it spread to other parts of the world ${ }^{1}$. Sugarcane is a native of tropical Indian subcontinent and Southeast Asia. Sugar industry ranks second amongst major agrobased industries in India. In India, sugarcane is planted thrice a year in October, March and July depending on part of the country. The majority of the sugar production in India takes at local Cooperative Sugar mills ${ }^{2}$. After Independence, India made serious plans for overall industrial development of sugar industry ${ }^{3}$.

The Indian sugar industry is independent in its energy needs and further makes additional exportable power through cogeneration. The different byproducts of sugar industry likewise add to the economic development of the nation to advancing various additional industries. Sugarcane has developed as a multi-product crop utilized as an essential raw material for the manufacture of sugar,
Article DOI: https://doi.org/10.36713/epra4748

ethanol, paper, electricity and besides a cogeneration of subsidiary product. The taking care of dairy cattle of sugarcane is significant source of bio-vitality and more demand in rural area. Molasses is an essential sustain stock for distilleries. The ethanol necessity of the nation is going up progressively. In sugar industry, creation of power utilizing biogases was the typical option and utilization of biogases as a substitute raw material for wood pulp for monetary and ecological sustainability.

\section{Importance of Workers' Participation in Management}

The relationship between workers and employer will increasingly significant when they listen to each other and resolve issues commonly. The sugar industry must ensure that the participation of employees in the board of the industrial unit ought to be supported by utilizing of works committees, joint consultation and other techniques. This improves correspondence among administrators and workers, increase efficiency and lead to more prominent viability as group. The principle thought of workers participation in the administration is to expand workers impact in the administration by giving due acknowledgement to human component in the organization. The idea of workers participation is an endeavour with respect to the business to incorporate his representatives with a group which moves in the direction of the realisation of common objectives ${ }^{4}$.

\section{SELECT REVIEW OF LITERATURE}

Om Prakash $(1990)^{5}$ observes that the participative management seems to be quite a 
neglected aspect of organizational climate in public sector. Viable information system, appropriate forum, acceptable choice of representatives, adoption of employee stock share ownership plan, and indication of limits with regard to the powers of worker's representatives are major adjuncts of participative management.

Porter.E.L (1994) ${ }^{6}$ has examined the concept of participative management and job satisfaction among community college librarians in the United States. As community college librarians face increasing demands for new services related to the information technology revolution and for expanded instruction to students needing informational retrieval skills, they also face pressures to provide these services within budgetary constraints. The study examined the role played by participative management in contributing to job satisfaction among these librarians. Literature was reviewed showing how participative management contributes to the satisfaction of psychological, social and selffulfilment needs described Maslow and Herzberg. The function of participative management was also noted in the human relations theory of management, contingency management theory and the Total Quality Management model of management. The study confirmed that there was statistical evidence of a moderate correlation between participative management and job satisfaction.

Abhimanyu Kumar and AnshuTaunk (2012) ${ }^{7}$ have analyzed in their study and stated that several participative forums involving workers and management representatives work in the National Thermal Power Corporation (NTPC, Ramagundam) in Andhra Pradesh. The membership pattern in this participative forum reveals that they give an almost equal representation to both these categories. The workers representatives are capable of presenting their views quiet independently and freely in the meetings of the forums. The workers representatives are either elected by the workers themselves or by the trade union leaders. The study revealed that the management of NPTC Ramagundam in Andhra Pradesh is found to implement almost all the important decisions of the participative forums. The management with the help of workers ensures that they are capable of taking fruitful decision regarding policy making, service conditions, productivity, manufacturing and administration and supervision. Thus, it can be concluded that all these factors point out to the effective functioning of the scheme of participation of the workers in NTPC Ramagundam Andhra Pradesh.

Rathnakar $(2012)^{8}$ reveals that the workers will definitely get benefit, hence the participation is confined to all members in the organization and considers them at different levels of decision making. Employees agree that committee members share the information with their colleagues after meetings, the workers participation in management improves understanding between managers and workers and informed that joint management councils is the method of WPM which is used mostly in the organization.

Arun Kumar $(2016)^{9}$ has stated that the concept of workers participation management is a system of communication and consultation, either formal or informal, by which employees of an organization are kept informed about the affairs of an undertaking and through which they express their opinion and contribute to management decisions. Participation of workers in organizational decision making process in management in HEEP Haridwar unit of BHEL is sufficient or good. It is also helpful to create peaceful and harmonious environment in the unit and also helps in increasing the production and productivity in the unit.

BrijeshVerma and Ajay Pachauri (2017) ${ }^{10}$ have felt that the concept of workers participation in the management of industry is very important from the organization and from the individual point of view. The participation satisfies the people's higher order needs. Most of the persons in the organization aim at earning their livelihood but there are some others who take full interest in the organization, departments, their supervisors and fellow workers and they contribute towards achieving the organizational goals. The scheme of participation promotes industrial and human relations and thus helps minimizing the labour disputes because they participate in the process of decision-making and become the partners in those decisions. All the problems concerning the workers are settled.

\section{SCOPE OF THE STUDY}

The scope of this study is confined to the procedure of workers' participation in management in 'JUPITER' sugars India Ltd. Only. The outcomes of this study cannot be generalised to any other company.

\section{OBJECTIVES}

The specific objectives of this paper are

i. To assess the contemporary patterns of workers' participation in management in 'JUPITER' Sugars India Limited;

ii. To measure the level of satisfaction/dissatisfaction of employees/workers towards the contemporary patterns of workers' participation in management in 'JUPITER' Sugars India Limited;

iii. To identify the reasons for the dissatisfaction of employees/workers respondents towards the contemporary pattern of workers' participation in management in 'JUPITER' Sugars India Limited; 
iv. To offer the feasible ways and means to streamline the contemporary patterns of workers' participation in management in 'JUPITER' Sugars India Limited.

\section{RESEARCH METHODOLOGY}

The methodology consists of data collection from primary as well as secondary source. Through the survey method, the firsthand information was collected from 60 sample respondents from the study unit.

\section{Sample design and size}

A purposive-cum-convenient sampling technique was followed and 60 respondents were chosen as sample respondents from the study unit.

\section{Analysis of the data}

The information collected from the sample respondents was processed and tabulated scientifically and several statistical tools like (i) independent sample t-test; (ii) weighted mean scores; and (iii) ANOVA are calculated at appropriate levels.

\section{The Limitations}

1. The study is confined to only one sugar unit;

2. The size of the sample is 60 only where the number is very meagre.

\section{RESEARCH FINDINGS}

1. The present scheme of employee/workers' participation in management is not at all promoting the industrial harmony and human relations in the company and also not minimizing the industrial dispute prevailed in the company $(58.33 \%)$

2. In the process of the employee/workers' participation in management, the employees and employee representatives are not given freedom while taking the decisions and not making them as partners in taking decisions. The management representatives are taking monotonous decisions which are biased and prejudiced $(56.66 \%)$.

3. There are no proper senior HR executives in the company to look after the proper payrevisions and to review and implement them $(46.66 \%)$.

4. The present procedure of workers participation in management is not at all improving the quality of life of the employees/workers. So that the individual productivity of the employees is utterly lowering down $(53.33 \%)$.

\section{SUGGESTIONS}

1. The present scheme of employee participation in management should be redesigned immediately. In the proposed new scheme, the employees should be given at most freedom to freely represent their views in the participation. In order to encourage the participation of employees effectively, periodical conduct of the procedure of employee participation in management would help the individual employees for regular participation into the management decisions.

2. While taking the decisions in the process of employee participation in management, the consensus of the individual employees should be collected on the items to be discussed in the employee participation in management. Further, the decisions taken in the process should be circulated each and every individual employees and their opinions should be solicited. So that the individual dissatisfactions of the employees can be minimized.

3. Properly educated and experienced H.R executives like a post graduate in H.R management with atleast 10 years experience in H.R activities should be appointed as an H.R executive and reasonable sub staff should be given to him for operation of H.R activities effectively.

4. Proper and scientific procedure of workers' participation in management, which can improve the quality of life of the employees' can be evolved. So that the individual/productivity of the employees/workers can be enhanced enormously.

\section{REFERENCES}

1. Moxham, Roy (2002-02-07). The Great Hedge of India: The Search for the Living Barrier that Divided a People. Basic Books.

2. "NFCSF - National Federation of Cooperative Sugar Factories Limited". Retrieved 2019-0604. "Cooperative sugar mills seek sops to begin crushing in next season". The Financial Express. 2018-04-17. Retrieved 2019-06-04.

3. "Indian Sugar Industry, Sugar Industry in India, Sugar Industry, Sugar Industries". www.indianmirror.com. Retrieved 2019-06-04.

4. J.P.Kesari, "The System of Workers Participation in Management in India", Journal of Social Work, .37-48, 1998.

5. Om Prakash: "Public Sector Employee Participation and Custodian Management", Indian Journal of Public Enterprise, Allahabad, Vol.5, No.8, January 1990.

6. Porter.E.L.: "Participative Management and Job Satisfaction among Community College Librarians, Ph.D. Thesis, University of Houston, United States, 1994.

7. Abhimanyu Kumar, AnshuTaunk: "Workers Participation in Management: A case study of 
National Thermal Power Corporation", International Journal of Educational Research and Technology, Vol.3, December 2012, pp.4245.

8. Rathnakar.G.: "A Study of Workers Participation in Management Decision Making at BHEL, Hyderabad, International Journal of Marketing, Financial Services \& Management Research, 1(9), 2012, pp.135-141.
9. Arun Kumar: "Effectiveness of Workers Participation in Management in BHEL: A Case study", International Journal of Advance research in Computer Science and Managgement Studies, Vol.4, Issue.8, August.2016.

10. BrijeshVerma, Ajay Pachauri: "Significance of Workers Participation in Management in an Organization", International Journal of Science technology and Management, Vol.6, Issue 5, May 2017, pp 501-504. 